\title{
Rana catesbeiana virus Z (RCV-Z): a novel pathogenic ranavirus
}

\author{
Sai Majji ${ }^{1}$, Scott LaPatra ${ }^{3}$, Scott M. Long $^{1}$, Robert Sample $^{1}$, Locke Bryan ${ }^{1}$, \\ Allan Sinning ${ }^{2}$, V. Gregory Chinchar ${ }^{1, *}$
}

${ }^{1}$ Department of Microbiology, and ${ }^{2}$ Department of Anatomy, University of Mississippi Medical Center, Jackson, Mississipi 39216, USA

${ }^{3}$ Research Division, Clear Springs Foods, Buhl, Idaho 83316, USA

\begin{abstract}
A virus, designated Rana catesbeiana virus Z (RCV-Z), was isolated from the visceral tissue of moribund tadpoles of the North American bullfrog Rana catesbeiana. SDS-PAGE (sodium dodecyl sulfate polyacrylamide gel electrophoresis) analysis of viral proteins and sequence analysis of the amino terminal end of the major capsid protein showed that RCV-Z was similar to frog virus 3 (FV3) and other ranaviruses isolated from anurans and fish. However, analysis of restriction fragment profiles following digestion of viral genomic DNA with XbaI and BamHI indicated that RCV-Z was markedly different from FV3. Moreover, in contrast to FV3, RCV-Z contained a full-length copy of the viral homolog of eukaryotic initiation factor 2 alpha (eIF-2 $\alpha$ ). Experimental infection of bullfrog tadpoles with FV3 and RCV-Z demonstrated that RCV-Z was much more pathogenic than FV3, and that prior infection with FV3 protected them from subsequent RCV-Z induced mortality. Collectively, these results suggest that RCV-Z may represent a novel species of ranavirus capable of infecting frogs and that possession of a viral eIF- $2 \alpha$ homolog (vIF-2 $\alpha$ ) correlates with enhanced virulence.
\end{abstract}

KEY WORDS: Iridovirus · Ranavirus · Frog virus $3 \cdot$ Rana catesbeiana virus Z · eIF-2 $\alpha$ homolog • Virulence

\section{INTRODUCTION}

Ranaviruses (family Iridoviridae) have been linked to die-offs among freshwater fish, farmed and wild frogs, and salamanders (Chinchar 2002, Chinchar et al. 2005, Williams et al. 2005). Infections run the gamut from subclinical to fulminant, and it is not known whether differences in clinical outcomes reflect the inherent virulence of the virus itself, the particular host species infected, or the effect of immune suppression following environmental insult (Williams et al. 2005).

Following in vitro infection, frog virus 3 FV3, the type species of the genus Ranavirus, produces marked cytopathic effect (CPE) in a variety of cultured amphibian, piscine, and mammalian cells (Willis et al. 1985, Williams et al. 2005). Surprisingly, despite marked CPE in vitro, FV3 infections in vivo were generally not associated with severe disease. Consistent with this view, the isolation of an FU3 from the kidneys of ostensibly healthy adult leopard frogs Rana pipiens suggested that, at least in adult frogs, infection does not invariably result in clinically apparent disease (Granoff et al. 1966). However, the seemingly benign nature of FV3 infections in vivo may be a reflection of the life stage of the infected individuals. Tweedel and Granoff (1968) demonstrated that tailbud and hatching-stage embryos were rapidly killed by injection with as little as 900 plaque-forming units (PFU) embryo ${ }^{-1}$ of FV3, whereas older tadpoles (17 to $26 \mathrm{~mm}$ ) survived challenge with $10^{5} \mathrm{PFU}$, and injection of $10^{8} \mathrm{PFU}$ into the dorsal lymph sacs of adult $R$. pipiens produced no detectable disease. Recently these findings were confirmed and extended by Gantress et al. (2003) and Robert et al. (2005), who showed that Xenopus laevis tadpoles succumbed to FV3 infection, whereas immunocompetent adult frogs successfully cleared the virus. Interestingly, adult frogs depleted of CD8+ cells or exposed to sublethal irradiation succumbed to disease, suggesting that 
disease in mature frogs was linked to immune suppression. In addition, these investigators showed that FV3 has a strong tropism for the proximal tubular epithelium of the kidney, but rarely disseminates beyond that tissue unless host defenses are experimentally impaired or developmentally immature as in larvae (Robert et al. 2005). Collectively, these results indicate that FV3 possesses low virulence or pathogenicity in vivo when inoculated into immunocompetent adult frogs, but readily infects and kills frog embryos, larvae, and immunocompromised adults.

In contrast to the above studies, other members of the genus Ranavirus have been linked to die-offs of cultured frogs in China and Thailand, garden frogs in the UK, and wild frogs in Europe, South America, and North America (Cunningham et al. 1996, Hyatt et al. 2000, Zhang et al. 2001, Chinchar 2002, Pearman \& Garner 2005, Williams et al. 2005). Moreover, ranaviruses have been linked to die-offs of adult salamanders and fish, indicating that ranaviruses possess considerable pathogenic potential in cold-blood animals (Langdon et al. 1986, Jancovich et al. 2005). It is unclear whether recent die-offs among various frog species are due to one or more novel ranavirus species, or to pathogenic strains of FV3. Furthermore, it is not known if enhanced pathogenicity is inherent in the virus itself or reflects the effects of environmental insults that depress immunity and predispose to viral disease, e.g. crowding among farmed animals or exposure to toxic chemicals or other pollutants. Herein we report the isolation and characterization of a ranavirus that was responsible for a die-off among cultured American bullfrogs Rana catesbeiana at a commercial frog hatchery. The isolate, designated Rana catesbeinana virus Z (RCV-Z), shares marked sequence identity to FV3 and other ranaviruses within the major capsid protein (MCP) and shows a similar profile of protein synthesis in vitro. However, in contrast to a common laboratory strain of FV3, RCV-Z contains a full-length copy of the viral eIF- $2 \alpha$ homolog and displays a markedly different profile following digestion of viral DNA with BamHI and XbaI. These results suggest that RCV-Z may represent a distinct ranavirus species, rather than simply a pathogenic isolate of FV3. Furthermore, the presence of a RCV-Z homolog of eIF- $2 \alpha$ correlates with increased virulence suggesting that vIF- $2 \alpha$ may play an important role in ranavirus pathogenesis.

\section{MATERIALS AND METHODS}

Viruses and cells. FV3 was initially obtained from Allen Granoff (St. Jude Children's Research Hospital, Memphis, Tennessee, USA) and has been serially passaged in fathead minnow (FHM) cells following inoculation at a low multiplicity of infection (MOI). RCV-Z
(No. Z85-02) was isolated by S. L. from American bullfrog tadpoles collected at a commercial frog farm. Virus was isolated by homogenizing visceral tissue (kidney, spleen, and liver) from moribund tadpoles in 10 vol of Hanks's balanced salt solution and infecting epithelioma papillosum cyprini (EPC, European Collection of Animal Cell Cultures [ECACC] No. 93120820) and striped snakehead Channa striata (SSN-1, ECACC No. 96082808) cells with the resulting homogenate. Cultures were incubated at $17^{\circ} \mathrm{C}$ and observed daily for the development of CPE. Transmission electron microscopy was performed on sections from virus-infected EPC and FHM cells using standard techniques (Sample et al. 2006). FHM cells (American Type Culture Collection [ATCC] No. CCL 42) were used for virus propagation and metabolic labeling as described previously (Mao et al. 1997).

$\left[{ }^{35}\right.$ S $]$ methionine labeling and sodium dodecyl sulfate polyacrylamide gel electrophorensis (SDS-PAGE). Confluent monolayer cultures of FHM cells containing $\sim 2 \times 10^{6}$ cells per $35 \mathrm{~mm}$ dish were cultured in Dulbecco's minimum essential medium (DMEM) containing $4 \%$ fetal calf serum (FCS). Cells were either mockinfected or infected with FV3 or RCV-Z at a MOI of $\sim 20$ PFU cell ${ }^{-1}$, and, after $1 \mathrm{~h}$, the virus inoculum was removed and the cultures incubated at $26^{\circ} \mathrm{C}$ in DMEM containing $4 \%$ FCS. When CPE was evident $(\sim 24 \mathrm{~h}$ post infection, p.i.), the growth medium was removed and replaced with methionine-deficient Eagle's minimum essential medium with Earle's salts (EMEM) containing $20 \mu \mathrm{Ci} \mathrm{ml}^{-1}\left[{ }^{35} \mathrm{~S}\right]$ methionine and incubated for an additional $2 \mathrm{~h}$. After $2 \mathrm{~h}$, the radiolabeling medium was removed, the cells lysed in $250 \mu \mathrm{l}$ direct sample buffer (125 mM Tris-HCl, pH 6.8, 2\% SDS, 20\% glycerol, $2 \%$ 2-mercaptoethanol, and $0.01 \%$ bromophenol blue), and the lysate boiled for $3 \mathrm{~min}$. Lysates representing approximately equal numbers of cells were separated by electrophoresis on $10 \%$ SDS-polyacrylamide gels and the radiolabeled proteins were visualized by autoradiography (Laemmili 1970, Mao et al. 1997).

Viral DNA: restriction fragment length polymorphism (RFLP) analysis. Ten confluent $175 \mathrm{~cm}^{2}$ flasks of FHM cells were infected with FV3 or RCV-Z at a MOI of $0.01 \mathrm{PFU}$ cell $^{-1}$. After allowing $1 \mathrm{~h}$ for virus adsorption, $30 \mathrm{ml}$ of Eagle's minimum essential medium with Hank's salts (HMEM) containing $4 \%$ FCS were added to each flask and the cultures incubated at $26^{\circ} \mathrm{C}$ until $\mathrm{CPE}$ was extensive ( $48 \mathrm{~h}$ p.i.). At that time, the culture medium containing cell debris was frozen at $-80^{\circ} \mathrm{C}$ and the virus was released by 3 cycles of freeze-thaw. Viral DNA was isolated as described previously (Jancovich et al. 2003). Briefly, cell debris was removed by centrifugation at $2000 \mathrm{rpm}(650 \times \mathrm{g})$ for $15 \mathrm{~min}$ at $4^{\circ} \mathrm{C}$ in a GSA rotor (Sorval) and the clarified supernatant, designated $\mathrm{S} 1$, was held at $4^{\circ} \mathrm{C}$. The cell pellet was 
resuspended in $10 \mathrm{ml}$ of growth media using a Dounce homogenizer, the nuclei removed by centrifugation at $1500 \mathrm{rpm}(500 \times \mathrm{g})$ for $10 \mathrm{~min}$ at $4{ }^{\circ} \mathrm{C}$ using IEC rotor No. 269, and the clarified supernatant pooled with the $\mathrm{S} 1$ fraction. Virions were collected by centrifuging the $\mathrm{S} 1$ fraction at $30000 \mathrm{rpm}(100000 \times \mathrm{g})$ for $60 \mathrm{~min}$ at $4^{\circ} \mathrm{C}$ in a Beckman Type 55.2 Ti rotor, and the resulting virion pellet was resuspended in $10 \mathrm{ml}$ RSB $(10 \mathrm{mM}$ Tris- $\mathrm{HCl}_{1} \mathrm{pH} 7.6,10 \mathrm{mM} \mathrm{KCl}, 1.5 \mathrm{mM} \mathrm{MgCl}_{2}$ ). For the isolation of viral DNA and to remove adventiouslyassociated cellular DNA, concentrated virions (3 ml) were treated with DNAse $\left(200 \mu \mathrm{g} \mathrm{ml}^{-1}\right.$, Sigma) in the presence of $10 \mathrm{mM} \mathrm{MgCl}_{2}$ for $60 \mathrm{~min}$ at $37^{\circ} \mathrm{C}$. After $1 \mathrm{~h}$ the reaction was stopped by adding EDTA to a final concentration of $50 \mathrm{mM}$, and the virions were layered over a $20 \%$ (w/w) sucrose-RSB cushion and centrifuged at $30000 \mathrm{rpm}(150000 \times \mathrm{g})$ for $90 \mathrm{~min}$ at $4^{\circ} \mathrm{C}$ in a Beckman SW41 rotor. The overlay was removed by aspiration and the virion pellet was resuspended in TE buffer (10 mM Tris-HCl, pH 7.6, 1 mM EDTA) and digested overnight in the presence of $1 \% \operatorname{SDS}$ and $200 \mu \mathrm{g} \mathrm{ml}^{-1}$ Proteinase K (Qiagen) at $37^{\circ} \mathrm{C}$. The following day, viral DNA was extracted using phenol-chloroform. Viral DNA (10 $\mu \mathrm{g})$ was quantitated spectrophotometrically and digested overnight with HindIII, BamHI, or XbaI (Promega) at $37^{\circ} \mathrm{C}$, separated by electrophoresis on $1 \%$ agarose gels at $20 \mathrm{~V}$ for $\sim 26 \mathrm{~h}$, and visualized by staining with ethidium bromide.

Sequence analysis of viral major capsid protein (MCP) and vIF-2 $\alpha$ genes. PCR amplification was performed using oligonucleotide primers (Invitrogen) specific for a $\sim 500 \mathrm{bp}$ sequence at the $5^{\prime}$ end of the FV3 and RCV-Z MCP genes (forward primer: 5'GACTTGGCCACTTATGAC-3' and reverse primer: 5'-GTCTCTGGAGAAGAAGAA-3' [Mao et al. 1997] ) and the full-length vIF2 $\alpha$ genes (forward primer: 5'-CCGGGGATCCCCATGGCACACAACAGGTTT-3'; reverse primer: 5'-GGCCAAGCTTTTACACAAAGGG GCACA-3' [Essbauer et al. 2001]). Amplification reactions (50 $\mu$ l total volume) contained: $2.5 \mathrm{U}$ of IDPOL Taq polymerase (ID LABS), $10 \mathrm{mM} \mathrm{KCl}, 10 \mathrm{mM}$ $\left(\mathrm{NH}_{4}\right)_{2} \mathrm{SO}_{4}, 20 \mathrm{mM}$ Tris-HCl, $\mathrm{pH} 8.0,2 \mathrm{mM} \mathrm{Mg} \mathrm{SO}_{4}$, $0.1 \%$ Triton X-100, $0.1 \mathrm{mg} \mathrm{ml}^{-1} \mathrm{BSA}, 0.2 \mathrm{mM}$ each of dATP, dCTP, dGTP, and dTTP, along with $200 \mathrm{nM}$ of each primer. DNA was amplified using an initial cycle of $94^{\circ} \mathrm{C}$ for $5 \mathrm{~min}$, followed by 28 cycles of $94^{\circ} \mathrm{C}$ for $1 \mathrm{~min}, 45^{\circ} \mathrm{C}$ for $2 \mathrm{~min}$, and $55^{\circ} \mathrm{C}$ for $3 \mathrm{~min}$, and a final cycle of $72^{\circ} \mathrm{C}$ for $2 \mathrm{~min}$. Amplicons were cloned into pGEM-T Easy (Promega), and used to transform E. coli TOP 10 cells (Invitrogen). The presence of inserts specific for the MCP ( 500 bases) and vIF2 $\alpha$ ( 780 bases) genes was verified by digestion with EcoRI and the inserts were sequenced commercially (Seqwright) using M13F and M13R primers. The inferred amino acid sequences were aligned using the CLUSTAL V program in MEGALIGN (DNASTAR, Madison). The RCV-Z sequences were submitted to GenBank: vIF2 $\alpha$ (DQ083993) and MCP (DQ083394).

Rana catesbeiana disease outbreak. An increased incidence of morbidity and subsequent mortality occurred in a population of captive American bullfrog tadpoles. The tadpoles were progeny of adult American bullfrogs Rana catesbeinana that were reared in captivity in the absence of any acute disease outbreak. Tadpoles were fixed in $10 \%$ neutral-buffered formalin before paraffin embedding, sectioning and staining (Humason 1979).

Experimental infections. Two infection studies were carried out on American bullfrog tadpoles that had been reared on spring water during their entire life at the commercial frog farm where the epizootic had occurred. Groups of 10 tadpoles, approximately $10 \mathrm{~cm}$ in length, with about half possessing rudimentary legs, were infected intraperitoneally (i.p.) with FV3 or RCV$\mathrm{Z}$ (see Table 1 legend for doses). The tadpoles were monitored for $21 \mathrm{~d}$ and cumulative percent mortality determined. The virus was re-isolated and titered from each tadpole that died. In addition, randomly selected moribund tadpoles were fixed for histology in $10 \%$ neutral-buffered formalin as described above. To determine whether sublethal infection confers resistance to lethal challenge, surviving tadpoles from Expt 2 (see Table 1) were challenged i.p. with $10^{4}$ PFU RCV-Z. Finally, to determine if tadpole age influenced the outcome of infection, an additional experiment using smaller $(\sim 4 \mathrm{~cm})$ tadpoles was performed. A number of the surviving tadpoles from each experiment were also sacrificed and examined for the presence of virus.

\section{RESULTS}

\section{Rana catesbeiana disease outbreak}

In September 2002, a die-off with mortalities approaching $100 \%$ was observed at a commercial frog culture facility among tadpoles just prior to metamorphosis. The tadpoles were primarily affected after they grew legs but prior to complete tail loss. Three of 4 pens containing 5000 to 6000 tadpoles that were being reared on surface water were affected. It was estimated that approximately 15000 tadpoles died. Gross signs of disease included abdominal swelling, lethargy, and hemorrhages on the ventral surface. Histological examination of moribund tadpoles revealed enlarged hepatocytes with an amphophilic to basophilic tinctorial quality that was suggestive of a viral infection. Tadpoles that were being reared on spring water were not affected and the facility has not had another epizootic since converting all the rearing pens to spring water supplies. 


\section{Virus isolation and ultrastructural observations}

A virus, designated Rana catesbeiana virus Z, was isolated from the visceral tissues of moribund tadpoles. EPC and SSN-1 cells infected at $17^{\circ} \mathrm{C}$ with tissue homogenates showed multiple foci of refractile cells within $2 \mathrm{~d}$ and complete lysis by Days 5 to 7 . Plaque assays of supernatants from lytic cultures inoculated onto EPC and SSN-1 cell lines using standard methods (LaPatra et al. 1989) produced titers of $10^{6}$ to $10^{7} \mathrm{PFU}$ $\mathrm{ml}^{-1}$. Ultrastructural studies of infected EPC cells detected icosahedral particles with an outer capsid diameter of 130 to $155 \mathrm{~nm}$ and an inner capsid diameter of 65 to $90 \mathrm{~nm}$ (data not shown). Subsequent ultrastructural studies of RCV-Z-infected FHM cells showed features consistent with infection by an iridovirus, i.e. marked chromatin condensation, large, electronlucent assembly sites within the cytoplasm, and icosahedral virions within assembly sites, paracrystalline arrays, and budding at the plasma membrane (Fig. 1). The presence of a few viral particles ostensibly within the nucleus was unexpected, but may have been an artifact of fixation and sectioning, or a consequence of changes in the nuclear membrane accompanying apoptosis. Based on the species infected, disease characteristics, and ultrastructural findings, it was considered likely that RCV-Z was a member of the genus Ranavirus, family Iridoviridae (Chinchar et al. 2005). To determine if RCV-Z is a novel ranavirus species or a pathogenic strain of $\mathrm{FV} 3$, the isolate was further characterized by SDS-PAGE analysis of in vitro viral protein synthesis, RFLP (restriction fragment length polymorphism) analysis of viral genomic DNA, and sequence analysis of 2 key viral proteins, the highly conserved MCP and VIF- $2 \alpha$, the viral homolog of eIF-2 $\alpha$ (Mao et al. 1997).
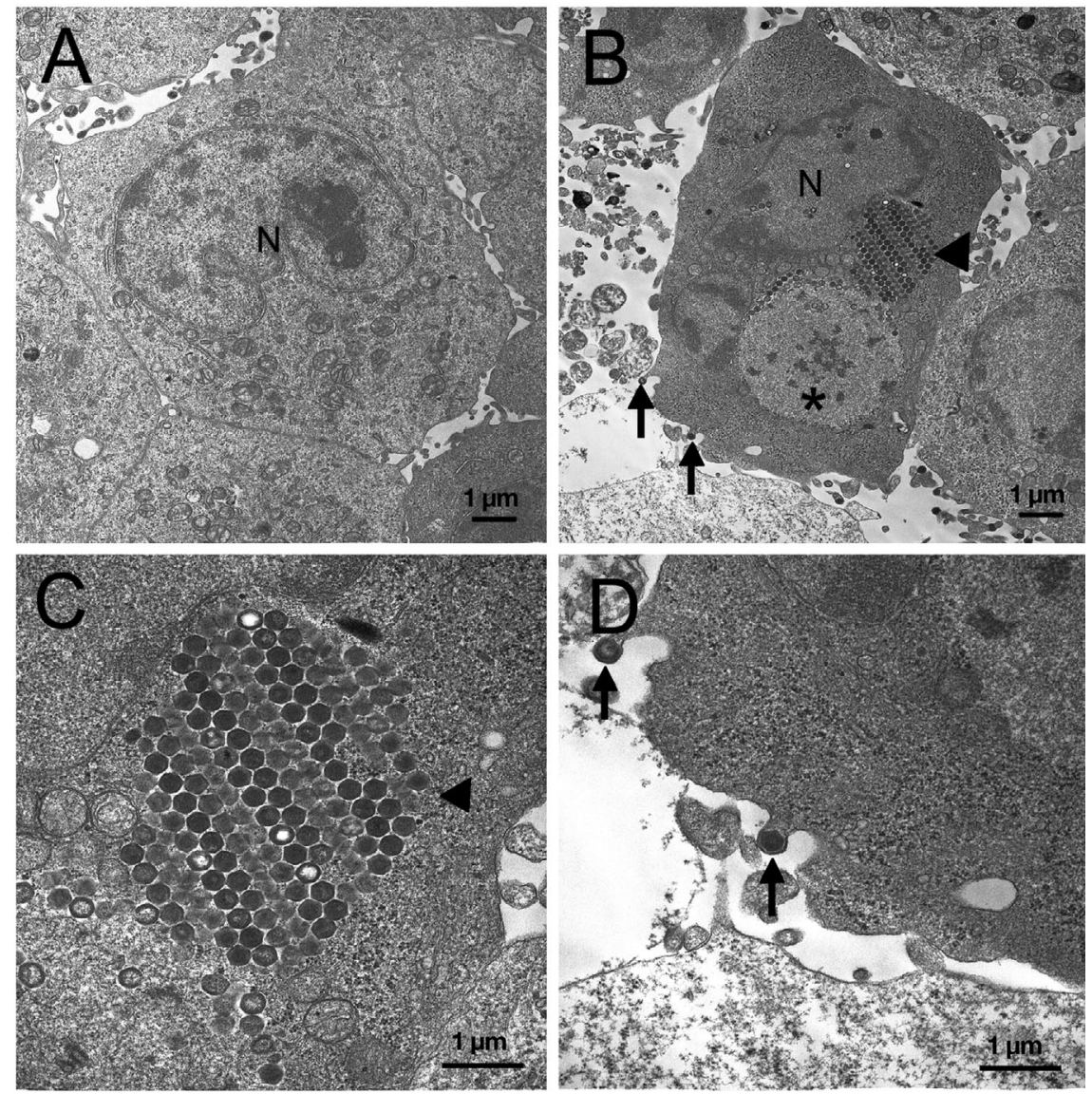

Fig. 1. Ultrastructural analysis of Rana catesbeiana virus (RCV-Z) infected (fathead minnow) FHM cells. Cells were mock-infected or infected with RCV-Z at multiplicity of infection of $\sim 20$ PFU cell ${ }^{-1}$ and at $9 \mathrm{~h}$ post infection processed for transmission electron microscopy. (A) Mock-infected FHM cells; (B) RCV-Z-infected FHM cells; (C) enlargement of paracryastalline array in (B); (D) enlargement of virion in (B) in process of budding from plasma membrane. N: nucleus; *: viral assembly site; arrowhead and arrows: virions within viral assembly sites and paracrystalline arrays (arrowheads), or budding from plasma membrane (arrows)

\section{Viral protein profiles}

FHM cells were infected with either FV3 or RCV-Z, and viral proteins were radiolabeled in vitro with $\left[{ }^{35} \mathrm{~S}\right]$ methionine. As shown in Fig. 2, the FV3 and RCV-Z protein profiles were similar and markedly different from the pattern seen in mock-infected cells. Viral infection led to the overall inhibition of host-cell protein synthesis and the translation of 20 or more virus-specific proteins, several of which are characteristic of ranavirus infection (Willis et al. 1985, Chinchar 2002). Moreover, although multiple bands of approximately similar size were detected in the FV3 and RCV-Z profiles, distinct differences in several bands were detected. For example, the RCV$\mathrm{Z}$ major capsid protein, an $\sim 48 \mathrm{kDa}$ protein that is one of the most prominent proteins in virus-infected cells (Willis et al. 1985, Chinchar 2002), migrates slightly slower than its FV3 counterpart. Although these results suggested that RCV-Z is likely a ranavirus, they did not allow us to determine whether it is a strain of FV3 or a member of a different virus species. 


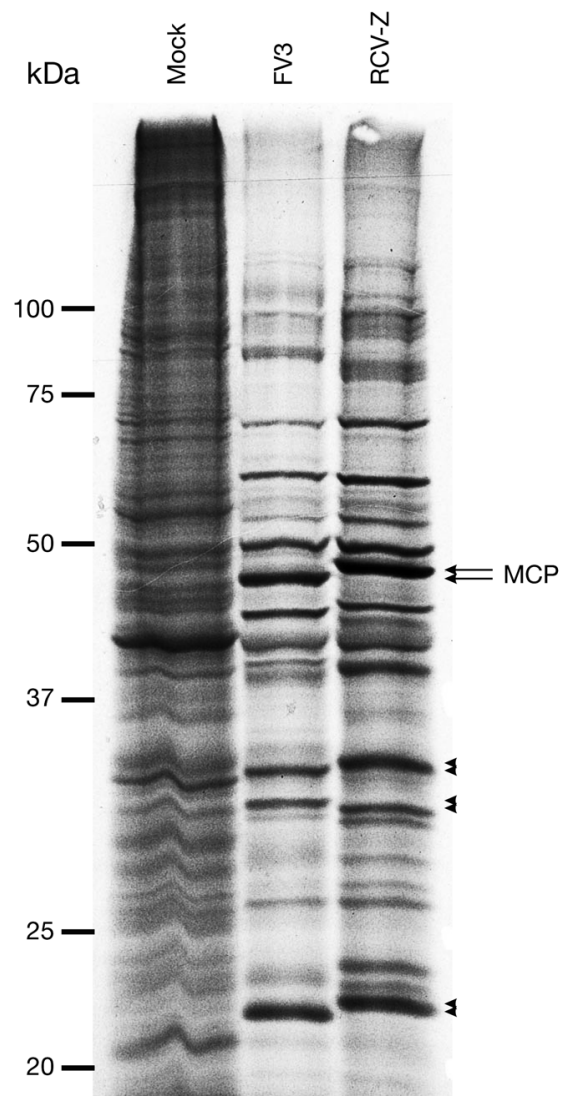

Fig. 2. Protein synthesis in frog virus (FV3) and RCV-Z infected FHM cells. FHM cells were either mock-infected or infected with FV3 or RCV-Z and radiolabeled with $\left[{ }^{35} \mathrm{~S}\right] \mathrm{me}-$ thionine as indicated in 'Materials and methods'. Radiolabeled proteins were separated by electrophoresis on $10 \%$ SDS-polyacrylamide gels and visualized by autoradiography. Molecular weight markers $(\mathrm{kDa})$ are given on the left; arrows indicate positions of the major capsid proteins (MCPs); arrowheads indicate 3 other viral proteins that display differences in electrophoretic mobility

\section{RFLP analysis}

To examine further the relatedness of FV3 and RCV-Z, viral DNA was digested with HindIII, BamHI, and $\mathrm{XbaI}$ (Fig. 3). HindIII digests of RCV-Z and FV3 showed that 4 of 6 bands were common to both viruses, whereas digestion with BamHI and XbaI generated markedly different patterns between the 2 viruses. It is likely that the large fragment migrating just slightly faster than the HindIII-A fragment in digests of RCV-Z DNA represents a fusion of neighboring HindIII fragments that arose due to the loss of intervening HindIII restriction sites. The striking differences in RFLP profiles between FV3 and RCV-Z are reminiscent of the differences seen among other recognized species within the genus Ranavirus and suggest that RCV-Z is likely not a strain of FV3, but rather a distinct ranavirus species (Mao et al. 1997, Hyatt et al. 2000).

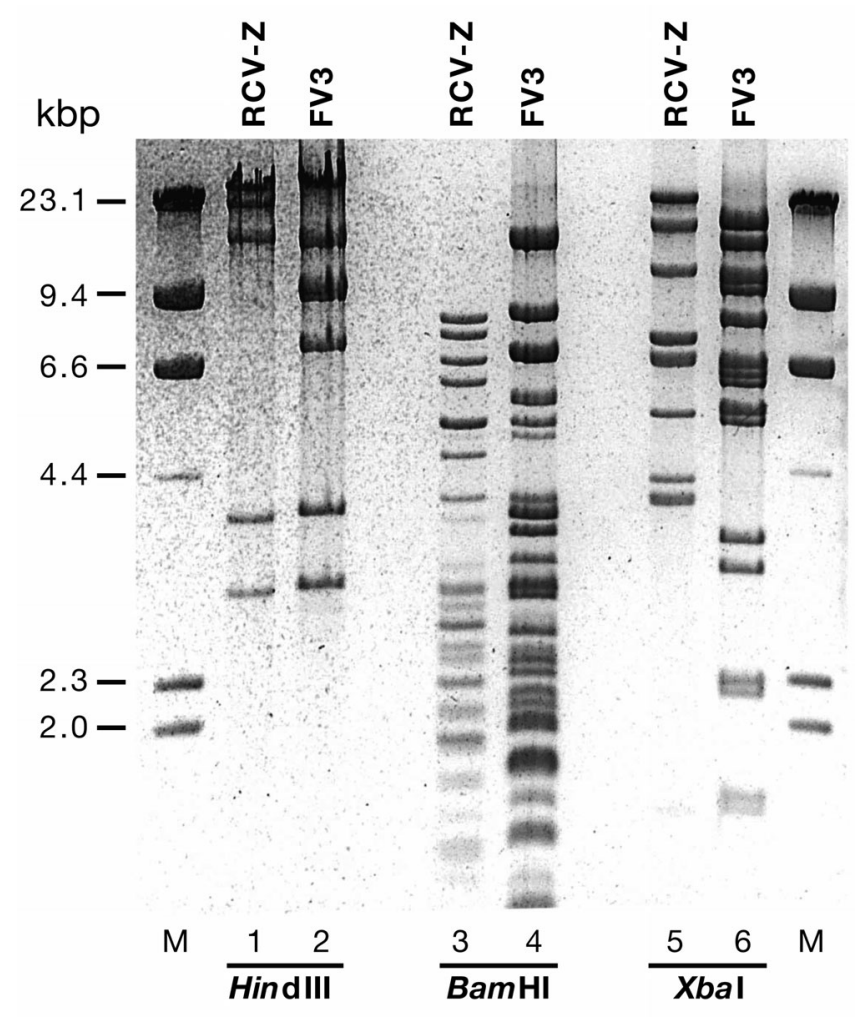

Fig. 3. RFLP analysis of FV3 and RCV-Z genomic DNA. Viral DNA, extracted from FV3 and RCV-Z virions, was digested with HindIII, BamHI, or XbaI, separated by electrophoresis on $1.0 \%$ agarose gels, and visualized by ethidium bromide staining. HindIII-digested bacteriophage lambda DNA was used as size marker (M)

\section{Sequence analysis of MCP and RCV-Z genes}

To clarify the taxonomic position of RCV-Z, 2 key viral genes encoding the MCP and the VIF- $2 \alpha$ proteins were cloned and sequenced. Sequence analysis of $\sim 500 \mathrm{bp}$ at the 5' end of the MCP gene confirmed that RCV-Z was a ranavirus since it showed $100 \%$ identity to ranavirus isolates from Chinese frogs (Rana grylio virus, RGV 9808) and Australian fish (epizootic hematopoietic necrosis virus, EHNV), $98 \%$ identity to isolates from North American salamanders (Ambystoma tigrinum virus, ATV) and Australian anurans (Bohle iridovirus, BIV), and $97 \%$ identity to FV3 (Fig. 4). Lower levels of sequence identity/similarity were seen with 2 more divergent ranaviruses, largemouth bass virus, LMBV (81\%) and Singapore grouper iridovirus, SGIV $(76 \%)$, and with lymphocystis disease virus (50\%), a member of the genus Lymphocystivirus. Phylogenetic analysis of iridovirus MCP sequences indicates that ATV, EHNV, RCV-Z, BIV, and FV3 comprise a wellsupported group of similar viruses that clusters apart from 2 more distantly related ranaviruses, SGIV and LMBV (Fig. 5). Moreover, since EHNV and FV3 are 
10

20

30

40

RCV-Z MCP : NLERAMYGGSDATTYFVKEHY PVGWFTKLPSLAAKMSGN PAFGQQ : 45 FV3_M $\overline{C P}:$ NLERAMYGGSDATTYFVKEHY PVGWFTKLPSLAAKMSGN PAF GQQ : 45 EHNV_MCP : NLERAMYGGSDATTYFVKEHYPVGWFTKLPSLAAKMSGNPAFGQQ : 45 RGV $\overline{9} 808$ : NLERAMYGGSDATTYFVKEHY PVGWFTKLPSLAAKMSGN PAFGQQ : 45 ATV_MCP : NLERAIYGGSDATTYFVKEHY PVGWFTKLPSLAAKMSGN PAFGQQ : 45 BIV MCP : NLERAMYGGSDATTYFVKEHY PVGWFTKLPSLAAKMSGN PAFGQQ : 45 LMBV_MCP : SLDKALYGGKDATTYFVKEHYPVGWFTKLPTAATKTSGTPAFGQH : 45 SGIV MCP : NLDRALYGGKDATTYFIKEHY PVGWFTKLPTMATR VSGN PAFGQE : 45 LCDV_MCP : EIEKYMYGGKTSTAYFVRETRKATWFTQVPVSLTRANGSANFGSE : 45

50 60 70 90 RCV-Z MCP: FSVGVPRSGDYILNAWLVLKT PEVKLLAANQLGDNGTIRWTKNPM : 90 FV3_M $\overline{C P}$ : FSVGVPRSGDYILNAWLVLKT PEVELLAANQLGDNGTIRWTKNPM : 90 EHNV MCP : FSVGVPRSGDYILNAWLVLKT PEVKLLAANOLGDNGTIRWTKNPM : 90 RGV_ $9808:$ FSVGVPRSGDYILNAWLVLKT PEVKLLAANQLGDNGTIRWTKNPM : 90 ATV_MCP : FSVGVPRSGDYIINAWLVLKTPEVKLLAANQLGENGTIRWTKNPM : 90 BIV ${ }^{-}$MCP : FSVGVPR SGDYILNAWLVLKT PEVELLAANQLGDNGTIRWTKNPM : 90 LMBV_MCP : FSVGVPRSGDYVLNSWLVLKTPQIKLLAANQFNANGTIRWTKNLM : 90 SGIV MCP : FSVGVPRSGDYVLNAWLTLKTPEIKLLETNRL GANGTVRWTKNLM : 90 LCDV_MCP : WSAS ISRAGDYLLYTWLRVRI PSVTLLS TNQFGANGRIRWCRNFM : 90 110 120 130

RCV-Z MCP: HNIVENVNLSFNDI SAQS FNTAYLDAWS EYTMPEAKRIGYYNMIG : 135 FV 3 M $\bar{C} P$ : HNIVESVTLSFNDI SAQS FNTAYLDAWS EYTMPEAKRTGYYNMIG : 135 EHNV_MCP : HNIVENVNLSFNDISAQS FNTAYLDAWSEYTMPEAKRIGYYNMIG : 135 RGV $9808: H N I V E N V N L S F N D I S A Q S$ FNTAYLDAWS EYTMPEAKRIGYYNMIG : 135 ATV_MCP : HNIVENVNLSFNDISAQS FNTAYLDAWSEYTMPEAKRIGYYNMIG : 135 BIV ${ }^{-}$MCP : HNIVESVTLSFNDI SAQS FNTAYLDAWS EYTMPEAKRIGYYNMIG : 135 LMBV MCP : HNVVEHAALSFNEIQAQQFNTAFLDAWNEYTMPEAKRIGYYNMIG : 135 SGIV MCP : HNAVEHASLTFNDI CAQQFNTAYLDAWTQFNMCEGKRIGYDNMIG : 135 LCDV_MCP : HNLIRECSITFNDLVAAR FDHYHLDFWAAFTTPASKAVGYDNMIG : 135

140 150 160

RCV-Z MCP: NTSDLINPAPATGONGARVLPAKNLVLPLP : 165 FV3_M $\overline{C P}$ : NTSDLINPAPATGQDGARVLPAKNLVLPLP : 165 EHNV MCP : NTSDLINPAPA TGQNGARVLPAKNLVLPLP : 165 RGV 9808 : NTSDLINPAPATGQNGARVLPAKNLVLPLP : 165 ATV_MCP : NTSDLINPAPATGQNEARVLPAKNLVLPLP : 165 BIV ${ }^{-}$MCP : NTSDLINPAPATGQDGARVLPAKNLVLPLP : 165 LMBV_MCP : NTSDLVNPAPATDQAGARVLPAKNLVLPLP : 165 SGIV_MCP : NTSDMTNPTPAQGQDGARTLPSKNLVLPLP : 165 LCDV_MCP : NVSALIQPQPVPVAPATVSLPEADLNLPLP : 165

Fig. 4. Multiple alignment: ranavirus MCP. Deduced amino acid sequence of a 165 amino acid region located at N-terminus of RCV-Z MCP was aligned with the corresponding region from other ranaviruses using CLUSTAL V program within DNASTAR. Amino acids that differed from those in RCV-Z are indicated by shading. GenBank Accession Nos. for sequences used in the above alignment: RCV-Z (DQ083994), FV3 (NC006549.1), EHNV (Epizootic hematopoietic necrosis virus, AY187045.1), RGV-9808 (Rana gyrilo virus 9808, AY294406.1), ATV (Ambystoma tigrinum virus, AY150217.1), BIV (Bohle iridovirus, AY187046.1), LMBV (largemouth bass virus, AF080250.1), SGIV (Singapore grouper iridovirus, NC006549.1), LCDV (Lymphocystis disease virus, AY849391.1) tein from zebrafish, and K3L, a vaccinia virus protein which is thought to function as a pseudosubstrate for proteinkinase R (PKR) (Beattie et al. 1991). A shown in Fig. 6, there are 17 amino acids that are identical among ranavirus vIF- $2 \alpha$ proteins, zebrafish eIF- $2 \alpha$, and K3L, including the highly conserved KGY[V/I]D motif (Amino Acids 83 to 87) that is likely to be involved in the interaction between PKR and eIF-2 $\alpha$ (Beattie et al. 1991, Davies et al. 1992, Kawagishi-Kobayashi et al. 1997, 2000). Like Rana esculenta iridovirus (Essbauer et al. 2001), the RCV-Z vIF- $2 \alpha$ gene contains a stop codon at position 256 indicating that the mature protein is about $10 \%$ shorter than homologous proteins from EHNV, RTV, and ATV. Since the $\mathrm{N}$-terminus of vIF-2 $\alpha$ shares homology with eIF-2 $\alpha$ and is thought to bind PKR and function as a pseudosubstrate for PKR, it is likely that the loss of 25 amino acids at the $\mathrm{C}$-terminal end would not affect function. In contrast to RCV-Z, we did not detect a full-length copy of vIF$2 \alpha$ in our FV3 isolate (Tan et al. 2004). Rather, a fusion protein containing 10 amino acids from the $\mathrm{N}$-terminus of the neighboring upstream open reading frame (ORF) and 66 amino acids from the C-terminus of the vIF- $2 \alpha$ ORF was observed. Collectively, the above results (SDS-PAGE, RFLP, and sequence analysis of the MCP and VIF- $2 \alpha$ proteins) support the assertion that RCV-Z is a member of the genus Ranavirus and suggests that it may represent a novel viral species within the genus Ranavirus. recognized as distinct species within the genus Ranavirus (Chinchar et al. 2005), the divisions suggested by the phylogenetic tree are consistent with the RFLP analysis and support the view that $\mathrm{RCV}-\mathrm{Z}$ is likely to be a distinct viral species rather than a strain of FV3.

Sequence analysis of the RCV-Z vIF- $2 \alpha$ protein also confirmed that RCV-Z is a ranavirus. RCV-Z vIF- $2 \alpha$ showed $96 \%$ identity to a homologous protein from EHNV, 95\% to Rana tigrinum virus (RTV), and 93\% identity to ATV (Fig. 6). Moreover, in addition to the high levels of sequence conservation among ranavirus vIF- $2 \alpha$ proteins, there is limited, but likely functionally significant, sequence conservation between ranavirus vIF- $2 \alpha$ molecules and a representative eukaryotic eIF- $2 \alpha$ pro-

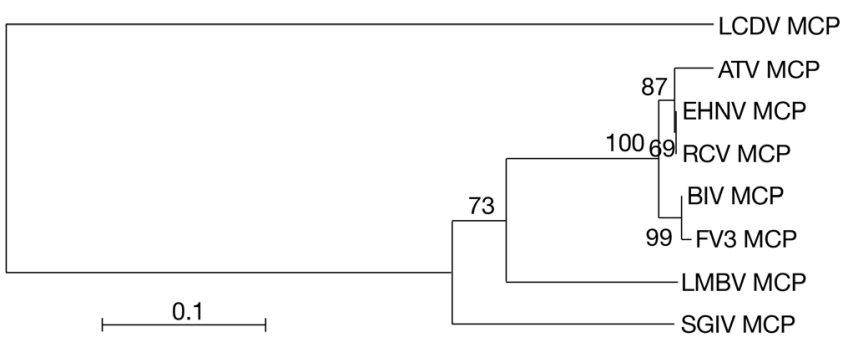

Fig. 5. Phylogenetic analysis of MCP sequences. Neighborjoining tree constructed using multiple alignment in Fig. 4 and algorithms present within MEGA 3 (Kumar et al. 2004). Degree of confidence for each branch point was determined by bootstrap analysis (1000 repetitions). LCDV was chosen as an outgroup. For virus abbreviations see Figs. $1 \& 4$ 


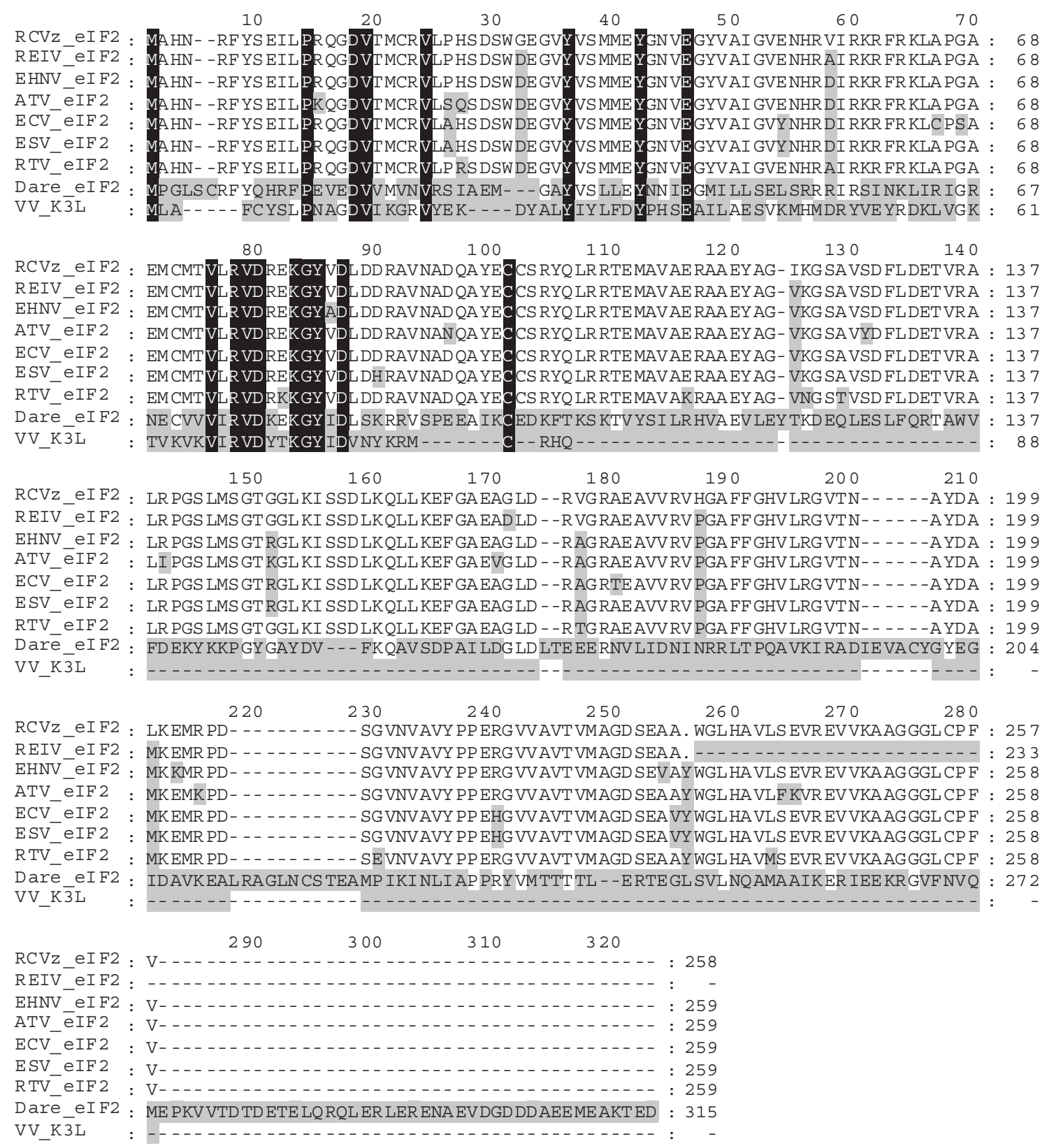

Fig. 6. Multiple alignment: vIF-2 $\alpha$ genes. Deduced amino acid sequence of RCV-Z vIF-2 $\alpha$ gene was aligned with corresponding genes of select iridoviruses, vaccinia virus K3L protein, and eIF- $2 \alpha$ gene of zebrafish Danio rerio using CLUSTAL V program within DNASTAR. Within the first 100 amino acids of the alignment, identity is indicated by black shading. Highly conserved region between Amino Acids 83 and 87 (KGY[I/V]D) represents eIF-2 $\alpha$ binding site. Differences between RCV-Z and the other proteins are indicated by gray shading. Sequences used in the alignment were RCV-Z (DQ083993), REIV (Rana esculenta iridovirus, AF213986.1), EHNV (epizootic heamatopoietic necrosis virus, AJ130965.1), ATV (Ambystoma tigrinum virus, AY150217.1), ECV (Ictalurus melas ranavirus, AF127911.1), ESV (Silurus glanis ranavirus, AF124437.1), RTV (Rana tigrina virus AF389451.1), Dare (Danio rerio, AAF68997), VV-K3L (vaccinia virus, NP063672)

\section{Experimental infections}

Since vIF- $2 \alpha$ is a virulence factor in some viral systems (Beattie et al. 1991, Davies et al. 1992, KawagishiKobayashi et al. 1997, 2000, Langland \& Jacobs 2002), we sought to determine the relative pathogenicity of
FV3 and RCV-Z by a series of experimental infections. In the first experiment, Rana catesbeiana tadpoles ( $\sim 10 \mathrm{~cm}$ in length) were infected with low doses of either FV3 or RCV-Z by i.p. injection. Injection of RCV-Z into tadpoles resulted in $100 \%$ mortality, whereas markedly less mortality was seen after FV3 
Table 1. Rana catesbeiana. Experimental infection of tadpoles with FV3 and RCV-Z. Data are no. of dead tadpoles/no. treated (\% mortality). Expt 1: tadpoles were injected i.p. with either FV3 (330 PFU tadpole ${ }^{-1}$ ), RCV-Z (113 PFU tadpole ${ }^{-1}$ ), or MEM, and percent mortality determined, Expt 2: 3 groups of 10 tadpoles each were injected i.p. with either $5.6 \times 10^{5} \mathrm{PFU}$ of FV3, $2.1 \times 10^{4} \mathrm{PFU}$ of RCV-Z, or MEM, and monitored for mortality

\begin{tabular}{|lccc|}
\hline Expt & FV3 & RCV-Z & MEM \\
\hline 1 & $1 / 10(10 \%)$ & $10 / 10(100 \%)$ & $0 / 10(0 \%)$ \\
2 & $0 / 10(0 \%)$ & $5 / 10(50 \%)$ & $0 / 10(0 \%)$ \\
\hline
\end{tabular}

injection (Table 1, Expt 1). To confirm the above results, another set of 10 tadpoles was inoculated with higher doses of FV3 or RCV-Z. None of the FV3infected tadpoles died, whereas half of the RCV-Zinfected tadpoles died (Table 1, Expt 2).

To determine whether sublethal infection confers resistance to lethal challenge, surviving tadpoles from Expt 2 (Table 1) were challenged i.p. with $10^{4} \mathrm{PFU}$ RCV-Z. As shown in Table 2, both FV3 and RCV-Z survivors were resistant to challenge by RCV-Z. However, 4 of 5 naïve tadpoles died following RCV-Z infection. This result was consistent with an earlier experiment in which 8 tadpoles that survived infection with a low dose of FV3 (Expt 1, Table 1) also survived subsequent challenge with $2.1 \times 10^{4} \mathrm{PFU}$ of RCV-Z (data not shown). Finally, to determine if tadpole age influenced the outcome of infection, an additional experiment using smaller $(\sim 4 \mathrm{~cm})$ tadpoles was performed. Tadpoles were inoculated with $8.4 \times 10^{4} \mathrm{PFU}$ of FV3 or $1.9 \times 10^{4} \mathrm{PFU}$ of $\mathrm{RCV}-\mathrm{Z}$ and monitored for disease symptoms. Although mortality in younger tadpoles injected with FV3 was higher than previously seen (4 of 6 injected tadpoles died), we were unable to isolate FV3 from any of the dead tadpoles, suggesting that death was not causally linked to virus infection. In contrast, all 7 tadpoles inoculated with RCV-Z died and the virus was readily isolated (data not shown). Collectively these results suggest that RCV-Z is more pathogenic than FV3, and indicate that prior sublethal infection with either FV3 or RCV-Z protected tadpoles from RCV-Z-mediated cell death.

Gross signs of disease in experimentally-infected tadpoles were very similar to those observed during natural infections and included abdominal swelling, lethargy, and hemorrhages on the ventral surface. Histological examination of moribund tadpoles revealed enlarged hepatocytes with an amphophilic to basophilic tinctorial quality that was seen previously in the naturally infected tadpoles. All the mortalities examined from the challenge studies except the 4 noted above were positive for virus (28 of 28) and plaque assay titers ranged from $2.0 \times 10^{3}$ to $>2.0 \times$
Table 2. Rana catesbeiana. RCV-Z challenge of RCV-Z and FV3 survivors. Data are no. dead/total no. injected. Surviving tadpoles from Expt. 2 (Table 1) were re-challenged with $10^{4}$ PFU of RCV-Z by i.p. injection and monitored for mortality. Control tadpoles were injected with virus-free tissue culture medium (MEM)

\begin{tabular}{|lccc|}
\hline Agent & FV3-survivors & RCV-Z survivors & Naïve animals \\
\hline RCV-Z & $0 / 10$ & $0 / 5$ & $4 / 5$ \\
MEM & Not done & Not done & $0 / 5$ \\
\hline
\end{tabular}

$10^{7} \mathrm{PFU} \mathrm{g}^{-1}$. A total of 31 mock-infected control individuals or challenge survivors were also tested for virus. Only 3 challenge survivors were virus positive and the titers ranged from 100 to $1400 \mathrm{PFU} \mathrm{g}^{-1}$. Virus was never detected in mock-infected controls.

\section{DISCUSSION}

Although criteria for defining ranavirus species are not straightforward, the distinctive RFLP profiles of RCV-Z and FV3 suggest that RCV-Z may represent a new species within the genus Ranavirus. Comparison with other ranaviruses indicates that strains of the same viral species show similar, but not necessarily identical, RFLP profiles, whereas viruses representing different species show markedly diverse protein and RFLP patterns. For example, independent studies by Mao et al. (1997) and Hyatt et al. (2000) observed that European sheatfish virus (ESV) and European catfish virus (ECV), doctor fish virus (DFV)/guppy virus 6 (GV6), and FV3, which represent 3 different ranavirus species (Chinchar et al. 2005), showed markedly different XbaI, KpnI, and HindIII RFLP profiles, whereas RFLP profiles in viruses considered to be isolates of a single species (i.e. ECV and ESV, and DFV and GV6, respectively) were highly conserved. However, despite unique RFLP profiles, RCV-Z and FV3, along with other members of the genus, showed marked similarities in SDS-PAGE profiles and displayed high levels of sequence identity within the highly conserved MCP gene. To determine the evolutionary relationships of these viruses, we generated a neighbor-joining tree (Kumar et al. 2004) using the MCP sequence information in Fig. 4. The MCP was chosen because (as suggested by Tidona et al. 1998), although it contains highly conserved domains, it is diverse enough to be used to distinguish among closely related isolates. The tree in Fig. 5 shows that ATV, EHNV, RCV-Z, BIV, and FV3 form a tight cluster of closely related viruses. Moreover, 4 of these viruses have been designated as viral species based on biological and genetic criteria (Chinchar et al. 2005). Because RCV-Z clusters apart 
from FV3, and because it possesses genetic (RFLP profiles) and biological (host range) differences from EHNV, it is likely to be a novel species within the genus Ranavirus, rather than simply a strain of FV3.

The absence of a full-length vIF- $2 \alpha$ gene in our isolate of FV3 was surprising in light of its reported presence in other ranaviruses including FV3 (Essbauer et al. 2001). The reason for this discrepancy is not known but may reflect different sources of FV3 or different passage histories. Tan et al. (2004) found no evidence for a full-length vIF- $2 \alpha$ gene within the FV3 genome. Instead, a truncated open reading frame corresponding to the C-terminus of vIF- $2 \alpha$ was seen. The viruses used in the current study and the virus sequenced by Tan et al. (2004) were originally obtained from Allan Granoff and are likely identical. They have been serially passaged in vitro for over $20 \mathrm{yr}$, and while virus titers have remained high (indicative of the absence of defective interfering particles), it is possible that in vitro passage selected for virus that, while well-suited for growth in FHM cells, has lost genes required for growth in vivo. This result is consistent with experience with other viruses in which serial passage attenuates virulence and results in the loss of viral genes (Miller 1996, Flint et al. 2004).

The increased pathogenicity of RCV-Z compared to FV3 may reflect the presence or absence of specific virulence genes such as vIF-2 $\alpha$. While it is not completely clear what role vIF- $2 \alpha$ plays in pathogenesis, vIF- $2 \alpha$ may modulate virulence on at least 2 levels. As illustrated in Fig. 7 , vIF- $2 \alpha$ may maintain viral protein synthesis in the face of a progressive shut-off of cellular translation. By analogy to the K3L protein of vaccinia virus, the ranavirus vIF- $2 \alpha$ protein may act as a pseudosubstrate for PKR, the dsRNA-activated protein kinase that phosphorylates and inactivates eIF-2 $\alpha$ (Beattie et al. 1991, Davies et al. 1992, Kawagishi-Kobayashi et al. 1997). By binding PKR, vIF-2 $\alpha$ may block the phosphorylation and inactivation of eIF-2 $\alpha$, and thus maintain viral protein synthesis in infected cells. However, because FV3 shuts off host translation, efficiently synthesizes its own proteins, and replicates to high titer without the benefit of a fullsize vIF- $2 \alpha$ gene, vIF- $2 \alpha$ is apparently not essential for replication in FHM cells (Willis et al. 1985, Chinchar \& Dholakia 1989). Interestingly, poxvirus mutants lacking the K3L gene are replication competent in many cell types because a second viral gene, E3L, is able to bind dsRNA and prevent PKR activation and subsequent eIF-2 $\alpha$ phosphorylation (Langland
\& Jacobs 2002, Smith \& Alcami 2002). Whether FV3 also contains a gene functionally similar to E3L remains to be determined. Although the ability of FV3 and the vaccinia virus K3L mutant to replicate in most cell types indicates that vIF- $2 \alpha$ is a non-essential gene, vaccinia virus replication in some cell types is markedly inhibited in the absence of K3L, suggesting that the viral homolog may play a role in viral hostrange and pathogenesis (Langland \& Jacobs 2002).

In addition to its putative role in maintaining viral protein synthesis, vIF- $2 \alpha$ may also play a role in blocking the host's immune response (Fig. 7). This suggestion is based on the observation that PKR activates $\mathrm{NF} \kappa \mathrm{B}$ by phosphorylating $\mathrm{I} \kappa \mathrm{B}$, an inhibitor of $\mathrm{NF} \kappa \mathrm{B}$ (Maran et al. 1994, Tan \& Katze 1999, Goodbourn et al. 2000, Williams 2001 [available at: www.stke.org/cgi/ content/full/OC_sigtrans;2001/89/re2], Gil et al. 2004); Following its phosphorylation, IкB is ubiquinated and
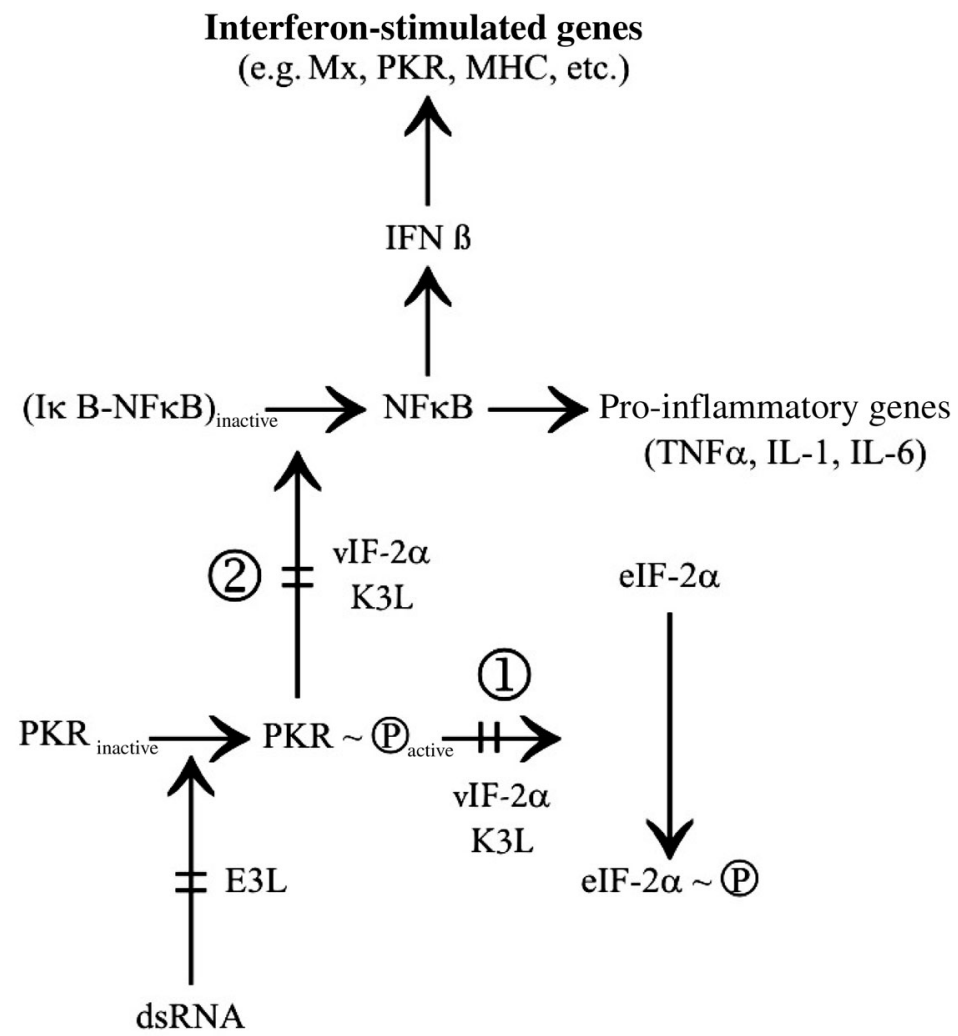

Fig. 7. Proposed role of PKR in NFאB activation and eIF2 $\alpha$ phosphorylation. Protein kinase R (PKR), present at low levels in uninfected cells and induced to high levels by interferon, is activated by binding to dsRNA. Activated PKR phosphorylates both eIF-2 $\alpha$ (Pathway No. 1), which results in a global inhibition of protein synthesis, and IкB (Pathway No. 2), which results in IKB's subsequent degradation and activation of pro-inflammatory response mediated by NFKB ( $\mathrm{P}$ indicates phosphorylation of the respective protein). By analogy to vaccinia virus K3L protein, vIF- $2 \alpha$ is thought to bind PKR and prevent phosphorylation of cellular eIF- $2 \alpha$ and thus maintain protein synthesis in virus-infected cells. If binding of PKR also blocks phosphorylation of IкB, then vIF- $2 \alpha$ may also play a role in arresting a pro-inflammatory response. See 'Discussion' for details 
subsequently degraded allowing the now unbound $\mathrm{NF} \kappa \mathrm{B}$ to translocate to the nucleus where it induces the synthesis of a variety of immune-related genes including interferon $\beta$ and pro-inflammatory cytokines such as TNF $\alpha$, IL-1, and IL-6 (Levy et al. 2003). We postulate that if PKR is sequestered by binding vIF- $2 \alpha$, then interferon production may be decreased and the proinflammatory response blocked. Although this mode of inhibition would not likely be operable in vitro when cultured cells are infected at high MOI, it may play an important role in vivo where control of virus infection relies on a vigorous and timely interferon and proinflammatory response. In an analogous fashion, the influenza A virus NS1 protein blocks activation of $N F \kappa B$ and the subsequent induction of interferon $\beta$ by binding dsRNA and preventing the activation of PKR (Wang et al. 2000).

While the above studies suggest that vIF- $2 \alpha$ is a possible virulence factor in ranaviruses, it should also be appreciated that virulence likely varies with the host species infected. Although our study suggests that Rana catesbeiana tadpoles are resistant to FV3 infection, Robert et al. (2005) and Tweedel \& Granoff (1968) showed that Xenopus laevis and $R$. pipiens tadpoles are sensitive to FV3-induced illness. Furthermore, Gantress et al. (2003) showed marked differences in time to death between an outbred strain of X. laevis and the inbred strain J. Similarly the response of $R$. latastei to FV3 infection varied between geographically distant populations consistent with the hypothesis that pathogenicity was influenced by the genetic makeup of the host species (Pearman \& Garner 2005). Finally, it should be pointed out that the absence of vIF- $2 \alpha$ does not ensure attenuation. SGIV, a newly identified ranavirus that is the most phylogenetically diverse member of the genus, is highly pathogenic in fish, but does not appear to contain an VIF- $2 \alpha$ gene (Song et al. 2004). Clearly, other iridovirus genes in addition to vIF- $2 \alpha$ may also play key roles in virulence.

Results from experimental infections suggest that frogs can be protected from virulent ranaviruses (e.g. RCV-Z) by prior exposure to a less pathogenic heterologous virus (e.g. FV3). These findings are similar to those for Bohle iridovirus in which knock out of the vIF-2 $\alpha$ gene generated a virus with decreased pathogenicity in vivo (A. Hyatt, J. Pallister, S. Gumely, and R. Voysey, unpubl.). Furthermore, vaccinia virus bearing a deletion of the E3L gene protects mice against challenge with virulent wild-type virus (Brandt et al. 2005). Moreover, since frogs are deficient in the expression of Major Histocompatability Complex (MHC) Class I antigens until after metamorphosis (Carey et al. 1999, Du Pasquier 2001), cell-mediated immunity is likely defective in larvae. Thus, the protection afforded by prior exposure to FV3 likely reflects the effect of anti-viral antibody. It is possible that protective antibodies are targeted to the highly conserved $\mathrm{MCP}$ and that anti-FV3 MCP antibodies cross-react with the RCV-Z MCP and neutralize virus infectivity. Whether antibodies to other conserved proteins also play a role in protection remains to be determined.

The above studies suggest that RCV-Z may represent a novel ranavirus species with enhanced pathogenicity in frogs. Moreover, the data suggest, but do not prove, that virulence is due to the presence of a viral homolog of eIF-2 $\alpha$. Additional studies are needed to determine if other viral genes also play a role in virulence. Moreover, to confirm the identification of vIF$2 \alpha$ as a virulence factor, it will be necessary to selectively delete this gene from wild-type virus and measure the effect of its loss on pathogenicity

Acknowledgements. This work was supported by awards No. DEB 02-13851 from the National Science Foundation and 1-S10-RR-11321-01A1 from the National Institutes of Health. We thank Glenn Hoskins (Department of Anatomy, UMMC) for expert electron microscopic analysis, and Bill Shewmaker and Aaron Weighall, Clear Springs Foods, for their excellent technical assistance.

\section{LITERATURE CITED}

Beattie E, Tartaglia J, Paoletti E (1991) Vaccinia virusencoded eIF- $2 \alpha$ homolog abrogates the antiviral effect of interferon. Virology 183:419-422

Brandt T, Heck M, Vijaysri S, Jentarra GM, Cameron JM, Jacobs BL (2005) The N-terminal domain of the vaccinia virus E3L protein is required for neurovirulence, but not induction of a protective immune response. Virology 333: $263-270$

Carey C, Cohen N, Rollins-Smith L (1999) Amphibian declines: an immunological perspective. Dev Comp Immunol 23:459-472

Chinchar VG (2002) Ranaviruses (family Iridoviridae): emerging cold-blooded killers. Arch Virol 147:447-470

Chinchar VG, Dholakia JN (1989) Frog virus 3-induced translational shut-off: Activation of an eIF-2 kinase in virusinfected cells. Virus Res 14:207-224

Chinchar VG, Essbauer S, He JG, Hyatt A, Miyazaki T, Seligy V, Williams T (2005) Iridoviridae. In: Fauquet CM, Mayo MA, Maniloff J, Desselberger U, Ball LA (eds), Virus taxonomy: 8th Report of the International Committee on the Taxonomy of Viruses. Elsevier, London, p 163-175

Cunningham AA, Langton TES, Bennet PM, Lewin JF, Drury SEN, Gough RE, MacGregor SK (1996) Pathological and microbiological findings from incidents of unusual mortality of the common frog (Rana temporaria). Philos Trans R Soc Lond B 351:1539-1557

Davies MV, Elroy-Stein O, Jagus R, Moss B, Kaufman RJ (1992) The vaccinia virus K3L gene product potentiates translation by inhibiting double-stranded-RNA-activated protein kinase and phosphorylation of the alpha subunit of eukaryotic initiation factor 2. J Virol 66:1943-1950

Du Pasquier L (2001) The immune system of invertebrates and vertebrates. Comp Biochem Physiol B 129:1-15 
Essbauer S, Bremont M, Ahne W (2001) Comparison of the eIF- $2 \alpha$ homologous proteins of seven ranaviruses (Iridoviridae). Virus Genes 23:347-359

Flint SJ, Enquist LW, Racaniello VR, Skalka AM (2004) Principles of virology, 2nd edn. ASM Press, Washington, DC

Gantress J, Maniero G, Cohen N, Robert J (2003) Xenopus, a model to study amphibian immune response to iridovirus. Virology 311:254-262

Gil J, Garcia MA, Gomez-Puertas P, Guerra S, Rullas J, Nakano H, Alcami J, Esteban M (2004) TRAF family proteins link PKR with NF-kB activation. Mol Cell Biol 24: $4502-4512$

Goodbourn S, Didcock L, Randall RE (2000) Interferons: cell signaling, immune modulation, antiviral responses, and virus countermeasures. J Gen Virol 81:2341-2364

Granoff A, Came PE, Breeze DC (1966) Viruses and renal carcinoma of Rana pipiens I. The isolation and properties of virus from normal and tumor tissue. Virology 29:133-148

Humason GL (1979) Animal tissue techniques. WH Freeman \& Co, San Francisco, CA

Hyatt AD, Gould AR, Zupanovic Z, Cunningham AA, Hengstberger S, Whittington RJ, Kattenbelt J, Coupar BEH (2000) Comparative studies of piscine and amphibian iridoviruses. Arch Virol 145:301-331

Jancovich JK, Mao J, Chinchar VG, Wyatt C and 7 others (2003) Genomic sequence of a ranavirus (family Iridoviridae) associated with salamander mortalities in North America. Virology 316:90-103

Jancovich JK, Davidson EW, Parameswaran N, Mao J, Chinchar VG, Collins JP, Jacobs BL, Storfer A (2005) Evidence for emergence of an amphibian iridoviral disease because of human-enhanced spread. Mol Ecol 14:213-224

Kawagishi-Kobayashi M, Silverman JB, Ung TL, Dever TE (1997) Regulation of the protein kinase PKR by the vaccinia virus pseudosubstrate inhibitor K3L is dependent on residues conserved between the K3L protein and the PKR substrate eIF2 $\alpha$. Mol Cell Biol 17:4146-4158

Kawagishi-Kobayashi M, Cao C, Lu J, Ozato K, Dever TE (2000) Pseudosubstrate inhibition of protein kinase PKR by swine pox virus C8L gene product. Virology 276:424-434

Kumar S, Tamura K, Nei M (2004) MEGA 3: Integrated software for molecular evolutionary genetic analysis and sequence alignment. Brief Bioinf 5:150-163

Laemmili UK (1970) Cleavage of structural proteins during assembly of the head of bacteriophage T4. Nature 227:680-685

Langdon JS, Humphrey JD, Williams LM, Hyatt AD, Westbury HA (1986) First virus isolation from Australian fish: an iridovirus-like pathogen from redfin perch, Perca fluviatilis L. J Fish Dis 9:263-268

Langland JO, Jacobs BL (2002) The role of the PKR-inhibitory genes, E3L and $\mathrm{K} 3 \mathrm{~L}$, in determining vaccinia virus host range. Virology 299:133-141

LaPatra SE, Roberti KA, Rohovec JS, Fryer JL (1989) Fluorescent antibody test for the rapid diagnosis of infectious hematopoietic necrosis. J Aquat Anim Health 1:29-35

Levy DE, Marie I, Prakash A (2003) Ringing the interferon alarm: differential regulation of gene expression at the

Editorial responsibility: Jo-Ann Leong,

Kaneohe, Hawaii, USA interface between innate and adaptive immunity. Curr Opin Immunol 15:52-58

Mao J, Hedrick RP, Chinchar VG (1997) Molecular characterization, sequence analysis, and taxonomic position of newly isolated fish iridoviruses. Virology 229:212-220

Maran A, Maitra RK, Kumar A, Dong B and 5 others (1994) Blockage of NF- $\mathrm{KB}$ signaling by selective ablation of an mRNA target by $2-5 \mathrm{~A}$ antisense chimeras. Science 265 : 789-792

Miller LK (1996) Insect viruses. In: Fields BN, Knipe DM, Howley PM (eds), Fundamental virology, 3rd edn. Lippincott-Raven, Philadelphia, PA, p 401-424

Pearman PB, Garner TWJ (2005) Susceptibility of Italian agile frog populations to an emerging strain of ranavirus parallels population genetic diversity. Ecol Lett 8:401-408

Robert J, Morales H, Buck W, Cohen N, Marr S, Gantress J (2005) Adaptive immunity and histopathology in frog virus 3-infected Xenopus. Virology 332:667-675

Sample RC, Bryan L, Long S, Majji S, Hoskins G, Sinning A, Olivier J, Chinchar VG (2006) Inhibition of iridovirus protein synthesis and virus replication by antisense morpholino oligonucleotides targeted to the major capsid protein, the $18 \mathrm{kDa}$ immediate early protein, and the viral homologue of RNA polymerase II. Virology (in press)

Smith VP, Alcami A (2002) Inhibition of interferons by ectromelia virus. J Virol 76:1124-1134

Song WJ, Qin QW, Qiu J, Huang CH, Wang F, Hew CL (2004) Functional genomics analysis of Singapore grouper iridovirus: complete sequence determination and proteomic analysis. J Virol 78:12 576-12 590

Tan SL, Katze MG (1999) The emerging role of the interferon-induced PKR protein kinase as an apoptotic effector: a new face of death? J Interferon Cytokine Res 19:543-554

Tan WGH, Barkman TJ, Chinchar VG, Essani K (2004) Comparative genomic analyses of frog virus 3, type species of the genus Ranavirus (family Iridoviridae). Virology 323: $70-84$

Tidona CA, Schnitzler P, Kehm R, Darai G (1998) Is the major capsid protein of iridoviruses a suitable target for the study of viral evolution? Virus Genes 16:59-66.

Tweedel K, Granoff A (1968) Viruses and renal carcinoma of Rana pipiens. V. Effect of frog virus 3 on developing frog embryos and larvae. J Natl Cancer Inst 40:407-410

Wang X, Li M, Zheng H, Muster T, Palese P, Beg AM, GarciaSastre A (2000) Influenza A virus NS1 protein prevents activation of NF- $\mathrm{kB}$ and induction of alpha/beta interferon. J Virol 74:11 566-11573

Williams T, Barbosa-Solomieu V, Chinchar VG (2005) A decade of advances in iridovirus research. Adv Virus Res 65:174-248

Willis DB, Goorha R, Chinchar VG (1985) Macromolecular synthesis in cells infected by frog virus 3. Curr Top Microbiol Immunol 116:77-106

Zhang QY, Xiao F, Li ZQ, Gui JF, Mao J, Chinchar VG (2001) Characterization of an iridovirus from the cultured pig frog Rana grylio with lethal syndrome. Dis Aquat Org 48: $27-36$

Submitted: December 19, 2005; Accepted: July 17, 2006

Proofs received from author(s): October 27, 2006 